OPEN ACCESS

Citation: Edward Entalai Besi, Farah Alia Nordin, Rusea Go (2020) Macro- and micro-morphologies and conservation status of Hymenorchis javanica (Orchidaceae: Aeridinae): the only representative of the genus in Malaysia. Webbia. Journal of Plant Taxonomy and Geography 75(2): 317-328. doi: 10.36253/jopt9498

Received: July 22, 2020

Accepted: August 18, 2020

Published: November 18, 2020

Copyright: (c) 2020 Edward Entalai Besi, Farah Alia Nordin, Rusea Go. This is an open access, peer-reviewed article published by Firenze University Press (http://www.fupress.com/webbia) and distributed under the terms of the Creative Commons Attribution License, which permits unrestricted use, distribution, and reproduction in any medium, provided the original author and source are credited.

Data Availability Statement: All relevant data are within the paper and its Supporting Information files.

Competing Interests: The Author(s) declare(s) no conflict of interest.

Editor: Riccardo M. Baldini

\section{Macro- and micro-morphologies and conservation status of Hymenorchis javanica (Orchidaceae: Aeridinae): the only representative of the genus in Malaysia}

\author{
Edward Entalai Besi ${ }^{1}$, Farah Alia Nordin², Rusea Go ${ }^{1, *}$ \\ ${ }^{1}$ Department of Biology, Faculty of Science, Universiti Putra Malaysia, 43400 Serdang, \\ Selangor Darul Ehsan, Malaysia \\ ${ }^{2}$ School of Biological Sciences, Universiti Sains Malaysia, 11800 USM, Penang, Malaysia \\ *Corresponding author. Email. rusea@upm.edu.my
}

\begin{abstract}
Analysis of morphological characters and conservation status were carried out for Hymenorchis javanica from Peninsular Malaysia. Morphology was studied in detail and accompanied by a botanical drawing prior to the correct identification. From most closely related Hymenorchis phitamii found in Vietnam, it differs in the lip ovate-oblong with apex acute and margins entire, and the leaves margins prominently serrulate. Based on the current IUCN criteria, we proposed H. javanica as an endangered species under the threatened category. Judging from the current small population sizes and degraded habitats, $H$. javanica in Malaysia is threatened by extinction in the wild.
\end{abstract}

Keywords: endangered species, climate change, Hymenorchis, Orchidaceae, taxonomy.

\section{INTRODUCTION}

Hymenorchis Schltr. is an orchid genus under subfamily Epidendroideae, tribe Vandeae and subtribe Aeridinae (Comber 1990). The genus comprises of small monopodial epiphytes that own short stems bearing leathery leaves with minutely serrulate margins (Rice 2018). The plant culminates axillary inflorescence with white to yellow flowers, free petals and sepals with serrulate margins, immobile and small green lip lamina, relatively large spur, and two pollinia (Comber 1990; Rice 2018). In Malaysia, Hymenorchis javanica (Teijsm. \& Binn.) Schltr. is the only representative of the genus. Hymenorchis javanica was previously claimed endemic to West Java at from 900-1000 m elev. (Comber 1990) and was many years then discovered in Mount Ulu Kali, Genting Highlands, Pahang, Malaysia (Ng et al. 2012; Govaerts et al. 2020). In Malaysia, this rare species is confined to a single population on a few trees on the roadside in Genting Highlands, which are now lessening in the location where it was spotted previously (Ng et al. 2012). Until now, no other plants 
nor localities were recorded in Malaysia, indicating rarity and vulnerability to local extinction with the current rate of forest conversion and environmental changes in the area. Genting Highlands is a resort development comprising hotels, casinos, shopping malls, and a theme park in Pahang that built on the peak of Mount Ulu Kali at 1,758 m elev. (Chua and Saw 2001; Genting Malaysia Berhad 2010). The summit area is located within the Bukit Tinggi Forest Reserve to the east and Batang Kali Forest Reserve to the west. Since 1967, rapid construction of roads and hotel complexes have had a detrimental impact on its physical environment and vegetation (Stone 1981; Chua and Saw 2001; Go et al. 2015a). Habitat destructions together with local climate change might have caused the orchid species to be eradicated locally or extinct (Go et al. 2015b). Collective findings from the previous floristic accounts and specimens deposited in the local herbaria and Singapore Botanic Gardens listed a total of 134 taxa and 51 genera of orchids in the Genting Highlands, including 33 endemic species to Peninsular Malaysia (Ng et al. 2012). The compilation includes a past collection by H.N. Ridley in Mount Mengkuang Lebah (Ridley 1914), William S. Null (Null 1972), B.C. Stone (Stone 1981), G. Seidenfaden and J.J. Wood (Seidenfaden and Wood 1992), R. Kiew (Kiew 1998), and a reassessment by FRIM in 1997 as a comparison to Stone's investigation (Chua and Saw 2001).

Hitherto no proper documentation on the occurrence of $H$. javanica in Malaysia nor the taxonomic description and illustration. Morphologically, H. javani$c a$ is highly identical to the Hymenorchis phitamii Aver. found in Vietnam. Both species are also occurring in montane forest (Averyanov et al. 2012; Ng et al. 2012). Vietnamese flora shows a strong similarity to tropical flora of Peninsular Malaysia at both family and generic levels (Zhu and Roos 2004). Therefore, the same orchid species may occur in both regions. Also, our specimens had not been thoroughly examined due to lack of floral structures and the small existing population as it is now at the current single locality. We thought it would be worth looking at the general morphology in detail to authenticate our earlier identification. Profiling on floral-surface micromorphology was conducted in order to enhance knowledge on the diversity and organographic distribution of the floral microstructures with inference to the taxonomic evaluation and physioecological demands. To the best of our knowledge that based on the plants growing in the Genting Highlands, H. javanica exhibits ephemeral, small and fragile flowers, and rarely flowering in the wild, as of Corybas, hence, a taxonomic study of the floral parts is noteworthy (Besi et al. 2019a).

\section{MATERIALS AND METHODS}

Specimen with complete floral structures was processed as herbarium specimens following Bridson and Forman (2000). The Copenhagen-preserved flower specimen was dissected, measured, described, and photos were taken for each of the significant part to assist the botanical drawing (Besi et al. 2020a). Plant descriptions and botanical drawings were based on the dissection of the spirit-preserved and fresh flower specimens. Classical taxonomy with reference to the type specimen, protologue, and botanical literatures of Smith (1903), Schlechter (1914) and Comber (1990) was employed in the identification process. Digitised images of herbarium collections, botanical drawing and records deposited in National Herbarium of the Netherlands (NHN) accessed through Browse Dutch Natural History Collections: BioPortal (Naturalis) (http://bioportal.naturalis. nl/) and Swiss Orchid Foundation (https://orchid.unibas. ch/index.php/en/) were studied in detail for both identification and evaluation of the species' distribution status. The accepted name was validated via KEW World Checklist of Selected Plant Families (WCSP) (Govaerts et al. 2020).

Floral-surface micromorphology examination was conducted using scanning electron microscope (SEM) in Anatomy Lab and Scanning Electroscope Room in the Faculty of Agriculture, UPM, Malaysia. The sample processing was made according to Spence (2001). The flower parts were cut into a number of $1 \mathrm{~cm}$ slices, put into separate vials, and fixed in formalin acetic acid. Then, the samples were post-fixed in $1 \%(\mathrm{v} / \mathrm{v})$ osmium tetroxide for overnight. After that, a series of ethanol was used in dehydration step; $50 \%, 75 \%, 90 \%, 95 \%$, and $100 \%(\mathrm{v} / \mathrm{v})$. The samples were dehydrated in each ethanol solution for 30 minutes and twice in the absolute one. The samples were then transferred into specimen baskets prior to critical point drying using liquid $\mathrm{CO}_{2}$ critical dryer for about 70 minutes. Dried samples were mounted onto the stub by means of double-sided carbon adhesive tabs and gold coated them in sputter coater. Finally, the samples were viewed under JEOL-JSM 5610 LV Scanning Electron Microscope. The floral-surface microstructures of dorsal sepal, lateral sepal, petals, lip, column, and pollinia were observed at various magnifications. The microstructures parameters observed were epicuticular waxes, epicuticular ornamentation, stomata, trichomes distribution and type, and pustular glands. Enumeration of trichomes requires four steps following Theobald et al. (1979). Parameter measurements were done using a ruler under a clear magnification and the values obtained were multiplied with the magnification scales. Epicuticu- 
lar ornamentation was described following Piwowarczyk (2015), Ghimire et al. (2018), and Kong and Hong (2018). Meanwhile, the description of epicuticular waxes was based on Wilkinson (1979). Enumeration of the micromorphological features was done following the outline in Ghazalli et al. (2019).

The current conservation status was validated through the IUCN Red List of Threatened Species database (http://www.iucnredlist.org). Assessment of the proposed conservation status was opined for $H$. javanica following a guideline in IUCN Red List Categories and Criteria version 14 (August 2019) (IUCN Standards and Petitions Committee 2019). The current information gathered were used in the assessment based on the geographical range in the form of the current Area of Occupancy (AOO) and Extent of Occurrence (EOO). The range of distributions was assessed using Geospatial Conservation Assessment Tool (GeoCAT) (http://geocat.kew.org/). This tool was for rapid geospatial analysis of the species in a simple yet reliable way. It supports the Red Listing process to help identify, evaluate against IUCN criteria, and conserve threatened species. The range of distribution from historical and current localities within Malaysia and Java was plotted in Google Earth maps. Extinction risk was determined based on Criterion B (IUCN Standards and Petitions Committee 2019).

\section{TAXONOMY}

Hymenorchis javanica (Teijsm. \& Binn.) Schltr., Repert. Spec. Nov. Regni Veg. Beih. 1: 995 (1913) (Figure 1 and Figure 2)

Basionym: Oeceoclades javanica Teijsm. \& Binn., Natuurk. Tijdschr. Ned. -Indië 24: 326 (1862);

(झ) Saccolabium javanicum (Teijsm. \& Binn.) J.J. Sm., Icon. Bogor.: t. 122 B (1903).

\section{Description}

Plants epiphytic, monopodial, small. Roots terete, thick, holding substrate. Stem short, ca. $1 \mathrm{~cm}$ long, having 4-6 distichous leaves, covered by finely spiky leaf sheaths. Internodes prominent, swollen, short. Leaves ca. $1.8 \mathrm{~cm} \times 0.8 \mathrm{~cm}$, ovate-oblong, apex acute, slightly conduplicate, dark green abaxially, paler green adaxially, thick, fleshy, margins finely serrulate distally, arranged at one plane. Inflorescence ca. 1-1.5 cm long, 4-8 flowered, flowers close to each other, arising from leaf axil in between sheaths. Pedicel-with-ovary ca. $6 \mathrm{~mm}$ long, arising from a single point at the posterior of leaves. Floral bracts ca. $2 \mathrm{~mm}$ long, triangular, acute, margin fimbri- ate, greenish. Flowers ca. $1 \mathrm{~cm} \times 0.6 \mathrm{~cm}$, large in proportion compared to the whole plant, flower including pedicel ca. $1 \mathrm{~cm}$, flower longer than broad, ca. $2 \mathrm{~cm}$ across, bell shape, odourless, resupinate. Sepals and petals free, thin, translucent white in colour, ovate to oblong with sharp tips, margins finely serrulate distally, prominent median outer keel. Dorsal sepal ca. $6 \mathrm{~mm} \times 3 \mathrm{~mm}$, ovate to oblong, apex widely acute. Lateral sepals ca. $6 \mathrm{~mm} \times$ $3 \mathrm{~mm}$, oblong, apex obtuse. Petals ca. $7 \mathrm{~mm} \times 4 \mathrm{~mm}$, ovate to elliptic, apex obtuse. Lip ca. $4 \mathrm{~mm} \times 2.6 \mathrm{~mm}$, fleshy, whitish with dark green patch at lamina, ovateoblong, almost oval, apex acute, margin entire, keeled basally, basal clawed and bent down, lamina small. Column ca. $4 \mathrm{~mm}$ long, stout, lacking foot, broad stigma, whitish. Anther-cap obovate. Spur ca. $4.8 \mathrm{~mm} \times 1.7 \mathrm{~mm}$, oblong, laterally flattened, pointing backwards parallel to ovary, whitish. Pollinia two. Infructescences 5-6 seedpods. Seedpods ca. $2 \mathrm{~cm}$ long, oblong, ridged on outer surface, green in colour.

\section{Etymology}

Hymenorchis is derived from Greek words, hymen (membrane) and orchis (orchid), descriptive of the delicate texture of the flowers (Schultes and Peace 1963). Latin javanica refers to Java, the type locality of this species.

\section{Distribution}

Genus Hymenorchis consists of fourteen species in the world (Govaerts et al. 2020). The centre of distribution of this species is in the Island of New Guinea and Philippines, except one outlying species, was far located in Java, H. javanica (Comber 1990; Schuiteman and de Vogel 2009). The species was an extremely endemic species to Java. It was found as trunk epiphyte in an open area near Mount Halimun, West of Bogor (Comber 1990). Then, this species was newly discovered for Malaysia region in Genting Highlands, an integrated hill resort development set amidst the cool mountain air and a majestic 100 million-year-old rainforest (Ng et al. 2012).

\section{Specimen examined}

MALAYSIA: Pahang, Genting Highlands, Mount Ulu Kali, ca. 1700 m elev., roadside, 14.5.2006, Edward Entalai Besi, Ng Yong Jin, Farah Alia Nordin, Rusea Go. NYJ148 (UPM!),

\section{Notes on habitat and current population in Malaysia}

The plants were discovered on a tree growing at the roadside in the summit area of Genting Highlands. The 


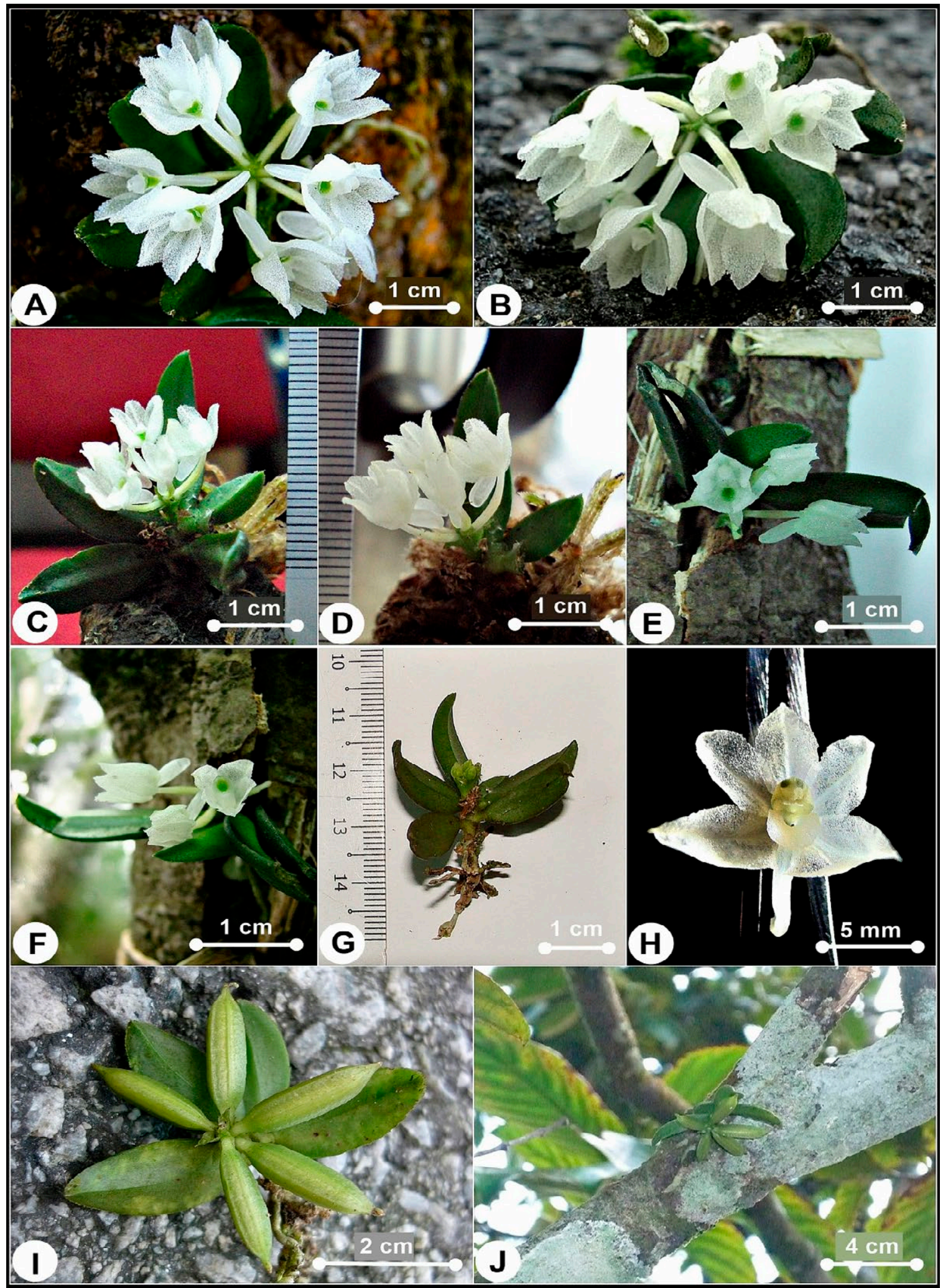

Figure 1. Hymenorchis javanica found in Genting Highlands. (A) Plant and flowers in the wild. (B) Plant and flowers, front view of the flowers. (C) Plant and flowers, lateral view. (D) Plant and flowers, back view. (E) Plant and flowers, top view. (F) Plant and flowers in ex-situ. (G) Plant with flowers in bud stage. (H) Flower (opened). (I) Plant with seedpods. (J) Plant on a tree at the roadside of Genting Highlands. 


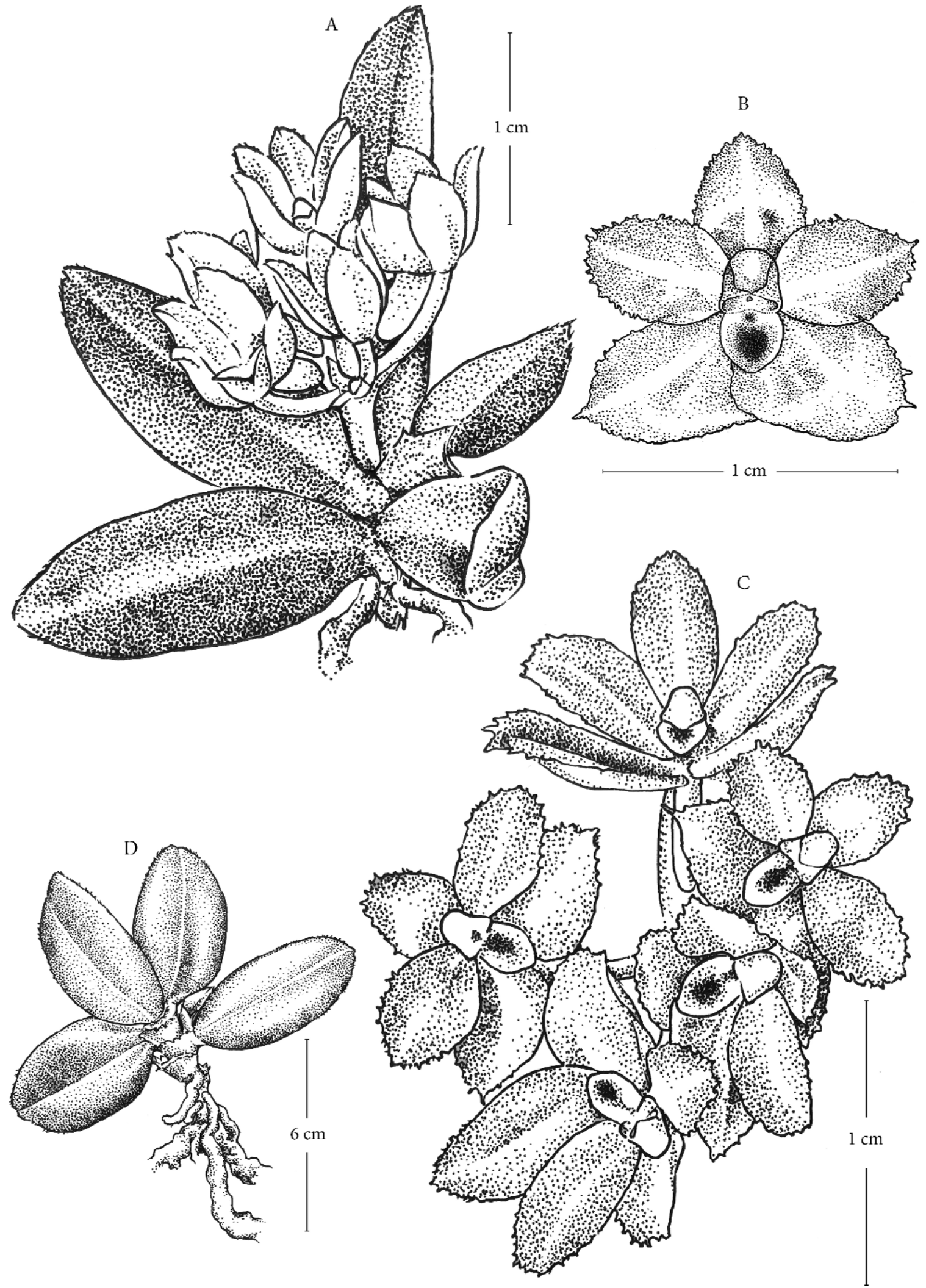

Figure 2. Hymenorchis javanica: (A) Plant with flowers. (B) Flower's front view showing serrulate margins of the tepals. (C) Flowers' top view showing ovate-oblong lip. (D) Plant. Drawn by Khalid Hashim. 


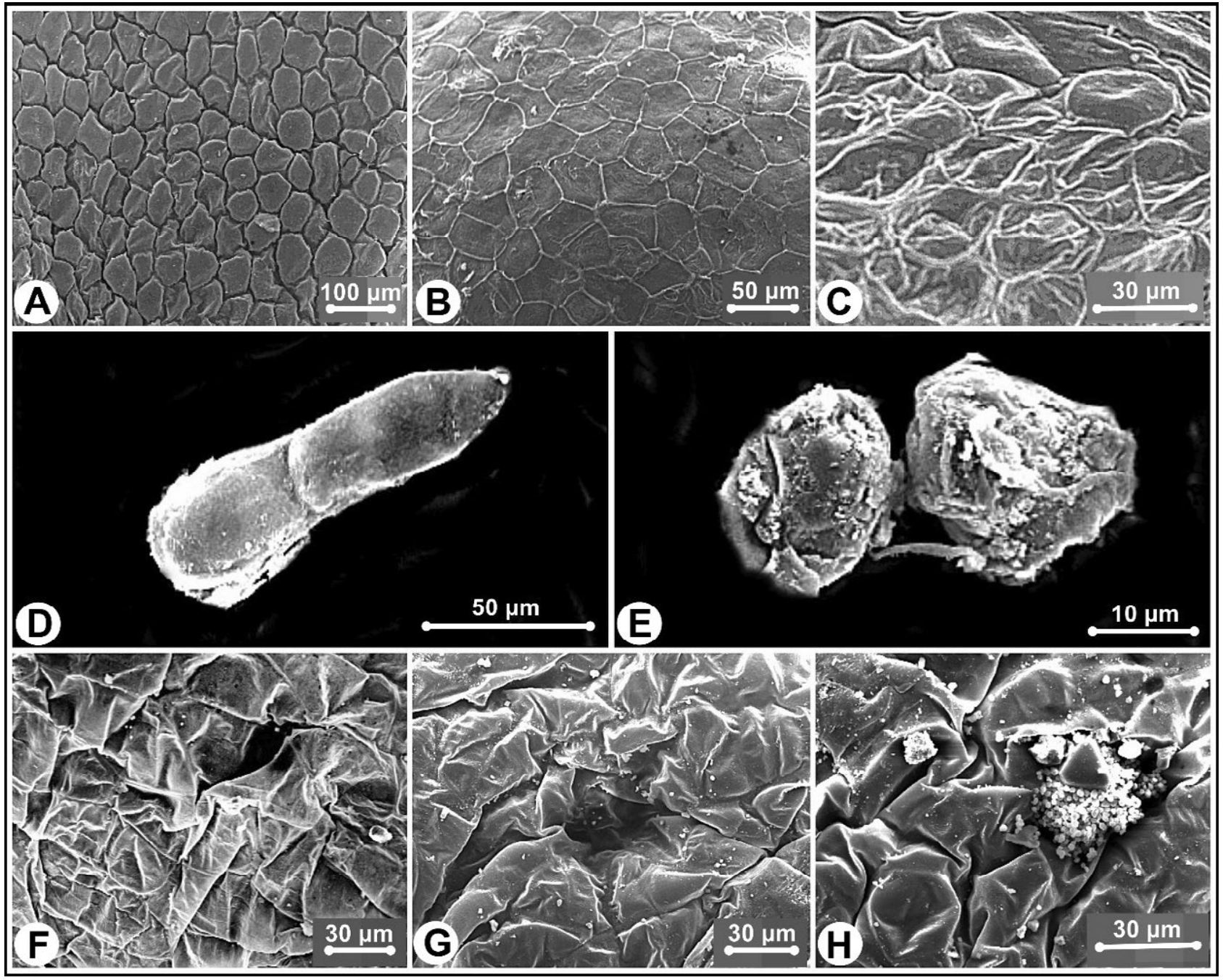

Figure 3. SEM observations of epicuticular ornamentation, trichomes, nectarostomata and waxes on surface of floral parts of $H$. javanica: (A) Type I epicuticular ornamentation on petals and sepals. (B) Type II epicuticular ornamentation on petals and sepals. (C) Type IV epicuticular ornamentation on pollinia. (D) Non-glandular, simple, multicellular trichomes occurring sparsely on the dorsal sepal and spur. (E) Warty-granulated waxes. (F) Type III epicuticular ornamentation on dorsal sepals. (G) Nectarostomata on spur. (H) Nectarostomata with globular waxes on spur.

summit area is considered as an upper montane forest (Whitmore and Burnham 1969). A montane forest developed for hotel and shopping complexes. There is a certain forest area of the summit area considered as a mossy elfin forest which is the sub-type of upper montane forest. The elfin forest is characterised by its stunted and twisted trees with its canopy of 5-7 $\mathrm{m}$ or less, dense and flattened crown, coriaceous leaves, and is indicated by species such as Dacrydium comosum Corner and Leptospermum polygalifolium Salisb. (Stone, 1981). There was merely one population of $H$. javanica about $10-20$ individuals found in the area.
Species references

Oeceoclades javanica Teijsm. \& Binn. (Teysmann and Binnendijk 1863); Saccolabium javanicum (Teijsm. \& Binn.) J.J.Sm. (Smith, 1903); Hymenorchis phitamii Aver. (Averyanov et al. 2012).

\section{Additional specimens examined}

MALAYSIA: Pahang, Bentong, Genting Highlands, Mount Ulu Kali, 16.12.2009, M. Firdaus MFK071 (UPM!); Indonesia: Java, Poentjoek (Puncak), 15.7.1908, Smith L1512749 (NHN-photo!). 
Species enumeration under SEM examination

Description (Figure 3): Waxes scattered, wartygranulated, and globular occurring on spur. Epicuticular ornamentation Type I: laevigate outer and polygonal periclinal wall; furrowed, straight and rounded anticlinal wall, on dorsal sepal, petals, lateral sepals, column and lip; Type II: laevigate and polyhedral outer periclinal wall; furrowed, straight and rounded anticlinal wall, on petals and sepals; Type III: laevigate-with-seams outer periclinal wall; furrowed, straight and rounded anticlinal wall, on spur; Type IV: foveate outer periclinal wall; fibrillary and undulate anticlinal wall, on pollinia. Stomata type and distribution nectarostomata on spur. Trichomes distribution present on dorsal sepal and spur. Trichomes type non-glandular, multicellular, short (ca. $100 \mu \mathrm{m}), 2$-tiers cells. Pustular glands sparsely present on the floral parts. Papillae absent.

\section{Conservation status assessment}

Based on the current IUCN Red List of Threatened Species, $H$. javanica has not yet been evaluated against the criteria. On the assessment of their proposed conservation status, $H$. javanica is here assessed as Endangered, EN B(2) (b)(iii), with the estimated AOO is 12 $\mathrm{km}^{2}$ and EOO is $36,932.713 \mathrm{~km}^{2}$. The AOO is less than $500 \mathrm{~km}^{2}$ and continuing decline in extent and quality of habitat (IUCN Standards and Petitions Committee 2019). Although the estimated EOO goes above the thresholds needed for a threatened category, however, the current collection localities in Malaysia and Java are within narrow AOO value (Figure 4). Our observation over the years including the visits by other colleagues without recollecting specimens show the current population on the few trees along the roadside of Genting Highlands are thinning of about 10 matured individuals if compared to when it was first found in scattered patches on several trees. The development in Genting Highlands has significantly affected the cloud forest in the summit area. Out of nine plots established by Stone, at least four had been replaced with buildings after 25 years (Chua and Saw 2001). Through the observation of change in species composition, there have been severe environmental changes in the summit area of Genting Highlands. This suggests that the fragmentation of forests may have damagingly impacted certain plant species (Chua and Saw 2001). Hence, a drastic conservation and preservation effort should be done to conserve this rare species from extinction and preserve its current habitat.

\section{DISCUSSION}

As reported above, now that there is a new Hymenorchis species discovered in southern Vietnam, H. phitamii, a congener that resembles $H$. javanica. It is deemed important to relook at the morphological description of $H$. javanica found in Malaysia to delineate these two cryptic species. The new record of $H$. javanica in Malaysia was mentioned in $\mathrm{Ng}$ et al. (2012), but it was not accompanied by a taxonomic description nor sufficient information on its occurrence and conservation status. Vietnamese plant looks closely similar with $H$. javanica on its vegetative characteristics and whitish flower that strikingly contrast with the small lip patched dark green on the lamina. Vegetatively, almost all species of Hymenorchis can be easily recognised by the finely serrulate leaf margin and fimbriate margin of leaf sheaths. These miniature plants with stem and leaves commonly not exceeding 1-2 cm long produce few relatively large white flowers arranged into a compact head-like inflorescence. The lip shape and accessory features in orchids, including the colour pattern, are useful in orchid classification and identification since the lip shows a wide variety of morphological diversity (Pridgeon et al. 1999). The $H$. phitamii differs from $H$. javanica in emarginate, long erose-dentate, almost orbicular lip, and hardly serrulate or even nearly entire straight margin of tepals and old leaves (Averyanov et al. 2012). Our botanical drawing illustrates the serrulated tepals and leaves, and ovateoblong and entire lip.

Taxonomic and physioecological aspects of the floral-surface micromorphology

The microstructures occurring on the floral parts of $H$. javanica provide no taxonomic significance due to the absence of diagnostic microcharacters, such as glandular trichomes, papillae, and rare type stomata. Only single type of trichomes occurring on the floral parts, the mutual short and multicellular non-glandular trichomes. The same goes for the epicuticular ornamentation that is lacking variation in morphology. Only the common ones with laevigate or foveate and polyhedral or polygonal periclinal walls were observed on the floral parts. These trichomes and epicuticular ornamentation types can be found in most of the floral parts of orchid species, including Corybas (Besi et al. 2019a), Crepidium (Besi et al. 2020b), Paphiopedilum (unpublished account), and Vanda (unpublished account). Clearly, the floral micromorphological characters are inconspicuous without a definite boundary to discriminate. Nevertheless, the microcharacters still offer significant notes on 


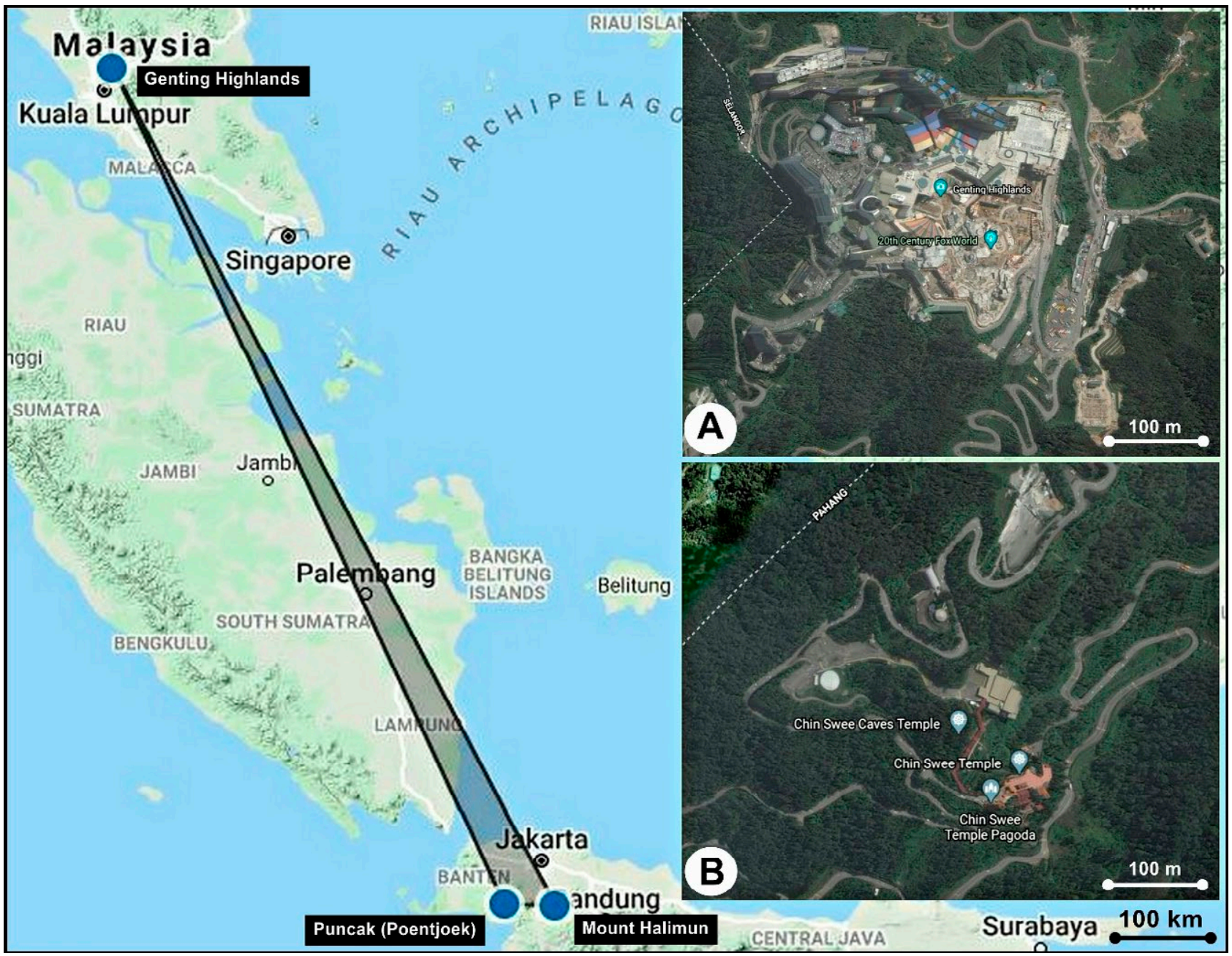

Figure 4. Extent of occurrence for H. javanica plotted with GeoCat: (A) Hotel and shopping complexes in Genting Highlands. (B) Road expansion in Genting Highlands.

the physioecological demands. Here, we deduce that the flowers offer rewards or nectar to the pollinators. This supported by the micrograph of the spur showing the presence of nectarostomata with waxy substance accumulated in it. Yet, absence of glandular trichomes, papillae and stomata on the floral parts, and lacking of waxes deposition on the sepals, petals and lip may suggest otherwise.

The flowers are not scented. Hence, the pollinator may be first attracted to the flower by the colour deceit alone, the bright white coloured tepals with a dark green patch on the ca. $2 \mathrm{~mm}$-wide lip lamina. The green patch glistening the lip draws the pollinator towards the opening of the spur. Then, the canaliculated claw at the base of the lip directs them straight to the spur. Though based an observation on some Bulbophyllum species, the median groove of the lip was often filled with liquid substance that visiting flies were seen to probe on (Ong and Tan 2012). However, the presence of liquid nor waxy substances on the lip of $H$. javanica was not presented in the micrograph, but a further observation on the pollinator visit in the field and cytochemistry may offer better inference. Also, lacking trichomes and waxes may suggest that flowers prone to desiccation and herbivorous insects (Davies and Turner 2004).

Threats to $H$. javanica and a proposal for conservation in Malaysia

Two major threats faced by all the montane plant species in tropical countries are local climatic changes and the conversion of forested areas for other use. Temperature rise and humidity drop are the two key param- 

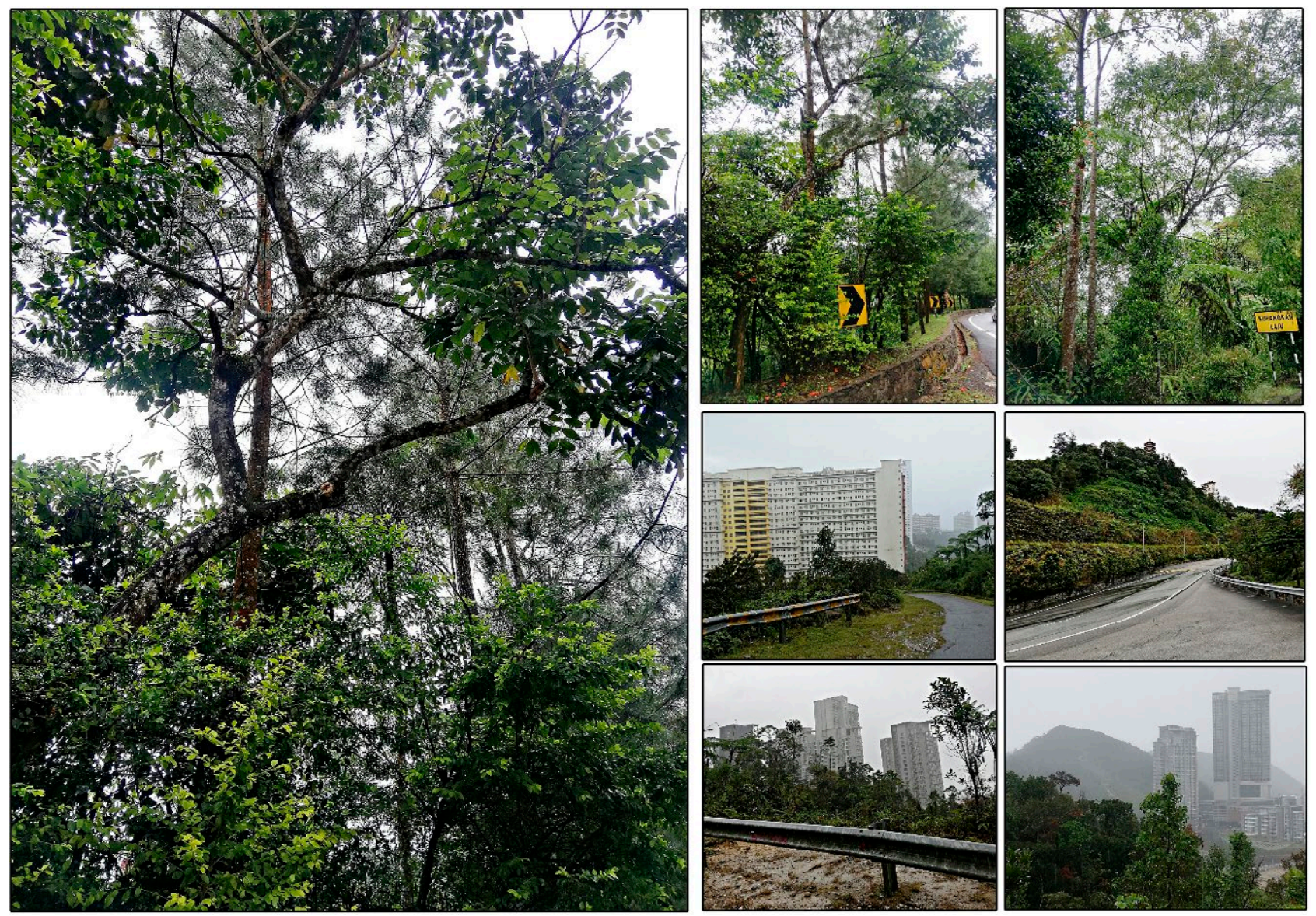

Figure 5. Habitat of H. javanica in Genting Highlands showing current on-going hotel complexes development and road expansion, and the host trees along the roadside.

eters that significantly impact the survival of many mountain peak endemic species in Peninsular Malaysia (Ng et al. 2012). The current habitat is now part of a road expansion for hotel development in the Genting Highlands (Ng et al. 2012) (Figure 5). This species should be monitored regularly or transferred to an ex-situ conservatory when necessary. Our ex-situ conservation trials in terraria placed in an air-conditioned room and controlled environment growth chamber were unsuccessful. Presumably, it might be probably due to the plants' sensitiveness and slow adaptation to sudden changes in irradiance, nutrients, and atmospheric-nitrogen deposition (Zhang et al. 2018). Also, the plants are lacking pseudobulbous organs that can store nutrients and water during dry periods (Yang et al. 2016; Besi et al. 2019b). Though epiphytic orchids have greater capacity to conserve water and avoid the damaging effects of drought based on their root functioning (Li et al. 2018).

Future studies should investigate the mechanisms that determine slow growth and flower induction of miniature orchids under both natural and ex-situ conditions. A good understanding of orchid physiology is essential for orchid conservation and utilisation. Besides small habits, species of the genus, including species described here, have a certain significance for horticulture as tiny miniature ornamental plants (Averyanov et al. 2012). The flowers are large in proportion to the rest of the plant which seems like to have a bell-shape. This makes it worthwhile to introduce it into cultivation. A plant conservatory can be built in the summit area in Genting Highlands to accommodate the ex-situ conservation. It is much more suitable to put the orchids from montane cloud forest habitat in a highland conservatory with fitting cold and moist conditions. This is a very practical way because no cost needed to equip a cooling system for cloud forest orchids. However, this does not mean that our highly treasured orchids can be simply taken out of its natural habitat. Only vulnerable orchid populations that a have large probability of losing their chance of survival should be planted in the conservatory. 


\section{CONCLUSION}

Our taxonomic treatment confirms the identification of $H$. javanica found in Malaysia. Also, our study underlines the role of the floral-surface micromorphological structures as protection and a potential site of nectar or food reward exudation. Though it offers no taxonomic significance due to the absence of diagnostic characters. Current local climate change has also impacted major mountain regions in Peninsular Malaysia, with evidence of thinning and declining of moss-carpeted forest floor seen in the Genting Highlands. More observations and evaluations will be required to confirm this. The most important limitation lies in our current study is the small existing population. The diminishing population of $H$. javanica in Malaysia restricts accessibility for further research on physioecology and micropropagation. The current habitat is not ideal for thorough observation to be made. We are therefore hoping to encounter more populations of this endangered plant prior to its conservation.

\section{ACKNOWLEDGEMENTS}

Support was given by the Forest Department Peninsular Malaysia, who granted us the access permit to the studied area. This work was partly sponsored by the UPM-KRIBB (Korea Research Institute of Bioscience and Biotechnology) grant (Vot. 6384300), FRGS-MOHE (Vot. 5524110), and UPM-Putra Grant (No. 9413603). This research was made possible by benefited from the sponsorships; Young Academic Scheme (TAM) issued by Universiti Putra Malaysia (UPM) and IPTA Academic Training Scheme (SLAI) issued by Ministry of Higher Education Malaysia (MOHE). We also gratefully acknowledge the help provided by our staffs and friends in the department. The authors contributed equally to this paper, and approved the paper for release and are in agreement with its content.

\section{REFERENCES}

Averyanov LV, Duy NV, Loc PK. 2012. Hymenorchis phitamii (Orchidaceae)-New genus and species in the Flora of Vietnam. Taiwania. 57(4): 372-376.

Besi EE, Nikong D, Mustafa M, Go R. 2020a. A New Species of Bromheadia Sect. Aporodes (Orchidaceae) from Terengganu, Peninsular Malaysia. Pakistan Journal of Botany. 52(3): 1019-1023.

Besi, EE, Nikong D, Mustafa M, Yong CSY, Go R. 2020b. Taxonomic placement of four confusable Crepidium species (Orchidaceae, Malaxidinae) based on macroand micro-morphological analyses, including a note on two new records to Peninsular Malaysia. Phytotaxa. 454 (1): 31-44.

Besi EE, Lai YE, Khor HE, Tan MC, Nulit R, Go R. 2019a. Floral Surface Micromorphology of Corybas selangorensis J.Dransf. \& G.Sm. and Corybas holttumii J.Dransf. \& G.Sm. (Orchidaceae). The Journal of the Orchid Society of India. 33: 47-56.

Besi EE, Nikong D, Mustafa M, Go R. 2019b. Orchid diversity in antropogenic-induced degraded tropical rainforest, an extrapolation towards conservation. Lankesteriana. 19(2): 107-124.

Bridson D, Forman L. 2000. The herbarium handbook, 3rd edition. Royal Botanic Gardens, Kew. 348 p.

Chua LSL, Saw LG. 2001). A reassessment of the flora of Gunung Ulu, Genting Highlands, Malaysia-Preliminary findings and trends. Malayan Nature Journal. 55(1\&2): 65-76.

Comber JB. 1990. Orchids of Java. Benthan-Moxon Trust, Royal Botanic Gardens, Kew. 407 p.

Davies KL, Turner MP. 2004. Morphology of floral papillae in Maxillaria Ruiz and Pav. (Orchidaceae). Annals of Botany. 93(1): 75-86.

Genting Malaysia Berhad. 2020. Genting Malaysia; [accessed 2020 January 10, 2020]. https://www.gentingmalaysia.com/

GeoCat. 2020. Geospatial Conservation Assessment Tool; [accessed 2020 July 2]. http://geocat.kew.org/

Ghazalli MN, Tamizi AA, Esa MIM, Besi EE, Nikong D, Nordin ARM, Zaini AZ. 2019. The systematic significance of leaf epidermal micro-morphology of ten Nepenthes species (Nepenthaceae) from Peninsular Malaysia. Reinwardtia. 18(2): 81-96.

Ghimire B, Jeong MJ, Suh GU, Heo K, Lee CH. 2018. Seed morphology and seed coat anatomy of Fraxinus, Ligustrum and Syringa (Oleeae: Oleaceae) and its systematic implications. Nordic Journal of Botany. 36(10): e01866.

Go R, Abdullah JO, Nordin FA, Siti Fatimah MI. 2015b. Orchids in the Montane Forests of Peninsular Malaysia. Universiti Putra Malaysia Press, Kuala Lumpur. $216 \mathrm{p}$.

Go R, Tan MC, Naruddin AA, Abdullah JO, Ng YJ, Nordin FA, Khor HE, Nulit R. 2015a. Extinction risks and conservation status of Corybas (Orchidaceae; Orchidoideae; Diurideae) in Peninsular Malaysia. Phytotaxa. 233(3): 273-280.

Govaerts R, Bernet P, Kratochvil K, Gerlach G, Carr G, Alrich P, Pridgeon AM, Pfahl J, Campacci MA, Baptista DH, Tigges H, Shaw J, Cribb P, George A, Kreuz K, Wood JJ. 2020. World Checklist of Orchidaceae. 
The Board of Trustees of the Royal Botanic Gardens, Kew; [accessed 2020 June 12]. http://apps.kew.org/ wcsp/.

IUCN Red List Categories and Criteria. 2020. The IUCN Red List of Threatened Species. Version 2020-1; [accessed 2020 June 10]. http://www.iucnredlist.org.

IUCN Standards and Petitions Committee. 2019. Guidelines for Using the IUCN Red List Categories and Criteria. Version 14. Prepared by the Standards and Petitions Committee; [accessed 2020 June 10]. http://www. iucnredlist.org/documents/RedListGuidelines.pdf.

Kiew R. 1998. The Seed Plant Flora of Fraser's Hill, Peninsular Malaysia: With Special Reference to Its Conservation Status. Forest Research Institute Malaysia, Kuala Lumpur. $121 \mathrm{p}$.

Kong MJ, Hong SP. 2018. The taxonomic consideration of floral morphology in the Persicaria sect. Cephalophilon (Polygonaceae). Korean Journal of Plant Taxonomy. 48(3): 185-194.

Li JW, Chen XD, Hu XY, Ma L, Zhang SB. 2018. Comparative physiological and proteomic analyses reveal different adaptive strategies by Cymbidium sinense and C. tracyanum to drought. Planta. 247(1): 69-97.

National Herbarium of the Netherlands (NHN). 2020. Browse Dutch Natural History Collections: BioPortal (Naturalis); [accessed 2020 May 10]. http://bioportal. naturalis.nl/

Ng YJ, Go R, Nulit R, Khor HE, Tan MC, Nordin FA, Nuruddin AA, Sook LN. 2012. Orchids of cloud forest in Genting Highlands, Pahang, Malaysia. Sains Malaysiana. 41(5): 505-526.

Null WS. 1972. The Phytosociology of Some Isolated Mountain Peaks in Peninsular Malaya. PhD dissertation. Syracuse University, New York. 247 p.

Ong PT, Tan KH. 2012. Three species of Bulbophyllum Section Racemosae pollinated by Drosophila flies. Malesian Orchid Journal 9: 45-50.

Piwowarczyk R. 2015. Seed micromorphology of central European Orobanche and Phelipanche (Orobanchaceae) in relation to preferred hosts and systematic implications. Australian Systematic Botany. 28(3): 124-136.

Pridgeon AM, Cribb PJ, Chase MW, Rasmussen FN. 1999. Genera Orchidacearum. Vol. 1: General Introduction, Apostasioideae, Cypripedioideae. Oxford University Press, Oxford. $197 \mathrm{p}$.

Rice R. 2018. Photo Intro to: Vandoid Orchid Genera in Asia. Nature and Travel Books Australia, Australia. $200 \mathrm{p}$.

Ridley HN. 1914. On a collection of plants from Gunong Mengkuang Lebah, Selangor. Journal of Federated Malay States Museums. 5: 28-50.
Schlechter R. 1914. Die Orchidaceen von Deutsch-NewGuinea. Repertorium specierum novarum regni vegetabilis, Beihefte. Vol. 1. 1079 p.

Schuiteman A, de Vogel E. 2009. Hymenorchis tanii. A new species from New Britain. Orchideenjournal 4: 151-153.

Schultes RE, Peace AS. 1963. Generic names of orchids: their origin and meaning. Academic Press, New York and London. $331 \mathrm{p}$.

Seidenfaden G, Wood JJ. 1992. The Orchids of Peninsular Malaysia and Singapore. Royal Botanic Garden, Kew. $779 \mathrm{p}$.

Smith JJ. 1903. Icones Bogorienses 2. Brill, Leiden. 328 p.

Spence J. 2001. Plant histology. In: C Hawes, B SataitJeunemaitre (eds.), Plant Cell Biology, A Practical Approach (pp.189-206). Oxford University Press, Oxford.

Stone BC. 1981. The summit flora of Gunung Ulu Kali (Pahang, Malaysia). Federation Museums Journal. 26(1): 1-157.

Swiss Orchid Foundation. 2020. Herbarium Jany Renz; [accessed 2020 May 10]. https://orchid.unibas.ch/ index.php/en/database-search/advanced-search

Teysmann JE, Binnendijk S. 1863. Plantae novae in horto bogoriensi cultae. In: HM Van Dorp, (ed.), Natuurkundig Tijdschrift voor Nederlandsch-Indie (pp. 305-332). Vijfde series, Deel 4, 521 p.

Theobald WL, Krauhulik JL, Rollins RC. 1979. Trichome description and classification. In: CR Metacalfe, L Chalk (eds.), Anatomy of dicotyledons (Second Edition) (Vol. 1, 294 p). Clarendon Press, Oxford.

Whitmore TC, Burnham CP. 1969. The altitudinal sequence of forests and soils on granite near Kuala Lumpur. Malayan Nature Journal. 22: 99-118.

Wilkinson HP. 1979. The plant surface (mainly leaf). In: CR Metacalfe, L Chalk (eds.), Anatomy of dicotyledons (Second Edition) (Vol. 1, 294 p). Clarendon Press, Oxford.

Yang SJ, Sun M, Yang QY, Ma RY, Zhang JL, Zhang SB. 2016. Two strategies by epiphytic orchids for maintaining water balance: thick cuticles in leaves and water storage in pseudobulbs. AoB Plants. 8: plw046.

Zhang S, Yang Y, Li J, Qin J, Zhang W, Huang W, Hu H. 2018. Physiological diversity of orchids. Plant diversity. 40(4): 196-208.

Zhu H, Roos MC. 2004. The tropical flora of southern China and its affinity to Indo-Malesian flora. Telopea. 10(2): 639-648. 
